\title{
Analisis Hukum Terhadap Kasus Kredit Macet Pada Bank Rakyat Indonesia Cabang Majene Nomor : 35/Pdt.G.S/2018/PN.Mjn
}

Oleh :

\author{
Lisma Resky Saputri, Kahar, Sulaeman \\ Universitas Sulawesi Barat \\ Email: $\underline{\text { lismareskisaputri@gmail.com }}$
}

\begin{abstract}
Abstrak
Dengan terjadinya penunggakan angsuran kredit yang dialami pihak Bank Rakyat Indonesia Cabang Majene dengan nasabahnya Siti Aminah dan Suddin, meski pihak Bank sudah memberikan keringanan kepada nasabahnya untuk melunasi angsuran kredit tersebut mereka tetap mengabaikan dan tidak membayarnya, maka pihak Bank mengajukan gugatannya ke Pengadilan. Menjadi masalah dalam penulisan ini apa yang menjadi dasar Pengadilan Negeri Majene mengadili gugatan kredit macet dibawah 40 juta dan bagaimana pertimbangan hakim dalam memutuskan perkara Nomor 35/Pdt.G.S/2018/PN.Mjn tentang Kredit Macet pada Bank Rakyat Majene. Dengan tujuan untuk mengetahui dasar Pengadilan Negeri Majene mengadili gugatan Kredit Macet dibawah 40 juta dan untuk mengetahui pertimbangan Hakim dalam memutuskan Perkara Nomor 35/Pdt.G.S/2018/PN.Mjn tentang Kredit Macet pada Bank Rakyat Majene. Metode penelitian menggunakan metode normatif empiris karena penelitian dilakukan terhadap putusan Pengadilan disertai dengan wawancara. Pengumpulan data menggunakan gabungan dari data sekunder dan data primer. Analisis data dilakukan yaitu Analisis normatif terutama mempergunakan bahanbahan hukum kepustakaan sebagai data penelitiannya dan dengan melakukan wawancara sebagai penambahan dalam mengambil data pertimbangan hukum hakim telah mempunyai kekuatan hukum tetap dan putusan tersebut sudah sesuai dengan peraturan-peraturan yang berlaku saat ini.
\end{abstract}

\section{Kata Kunci : Perjanjian kredit, kredit Macet, penyelesaian sengketa kredit macet}

\section{A. Pendahuluan}

Di Indonesia, lembaga perbankan mempunyai peranan yang sangat penting yaitu sebagai Agent of development dalam rangka mewujudkan pemerataan, pertumbuhan ekonomi dan stabilitas nasional. Sebagai salah satu pilar utama pembangunan nasional, industri perbankan harus mewujudkan tujuan perbankan nasional. ${ }^{1}$ Sebagaimana yangdisebutkan dalam Undang-undang Nomor 10 Tahun 1998 tentang Perbankan menyatakan bahwa Perbankan Indonesia bertujuan menunjang pelaksanaan pembangunan nasional dalamrangka meningkatkan pemerataan, pertumbuhan ekonomi dan stabilitas nasional ke arah peningkatan rakyat banyak. ${ }^{2}$

Pemberian kredit merupakan salah satu bentuk kegiatan usaha bank yang berkaitan dengan penyaluran dana bank ke masyarakat yang dapat dimanfaatkan oleh para pelaku ekonomi untuk mengembangkan dan memperbesar usaha-usaha mereka, baik yang

\footnotetext{
${ }^{1}$ http://www.google.com/search=Peranperbankanindonesia. Diakses tanggal 27 April 2012

${ }^{2}$ Malayu, S.P. Hasibuan, 2007, Dasar-dasar Perbankan, PT. Bumi Aksara, Jakarta, hal. 4
} 
secara langsung maupun tidak langsung dapat membantu terjadinya pemerataan pendapatan di masyarakat. Selain untuk mengembangkan usaha, fasilitas kredit perbankan dapat pula dimanfaatkan oleh masyarakat untuk memenuhi kebutuhan sekundernya seperti untuk pembelian rumah, barang-barang elektronik, kendaraan, dan lain- lain.

Dalam pemberian kredit, suatu bank pada hakikatnya harus mengambil resiko yang terkecil. Resiko yang dimaksud disini adalah resiko terhadap kemungkinan kredit itu tidak dapat dibayar kembali oleh debitornya. Oleh karena itu, setiap pemberian kredit tentunya telah memenuhi ketentuan Perbankan. Dengan demikian bank harus menyakini bahwa kredit yang diberikannya tersebut dapat melunasi kembali pada waktunya oleh nasabah atau debitor dan tidak akan berkembang menjadi kredit macet.

Bank Rakyat Indonesia (BRI) Cabang Majene merupakan salah satu pelaku sektor perbankan yang menjadi fasilitator penyalur kredit modal usaha yang berada di Sulawesi Barat.Bank ini menyediakan kredit konsumtif dan produktif. Kredit konsumtif merupakan kredit yang disediakan bank kepada debitur untuk memenuhi kebutuhan pribadi seperti kredit kendaraan bermotor, kredit Pemilikan Rumah (KPR), dan kredit Pegawai, sedangkan kredit produktif yaitu kredit yang disediakan pihak bank kepada debitur untuk mengembangkan usaha, seperti Kredit Modal Kerja dan Kredit Investasi. Kredit investasi dan kredit modal kerja merupakan kredit produktif karena digunakan untuk keperluan bisnis atau usaha, baik berupa modal kerja maupun investasi pembelian asset perusahaan, sehingga dapat menghasilkan dikemudian hari.Sedangkan kredit konsumtif digunakan untuk memenuhi kebutuhan sekunder masyarakat. ${ }^{3}$

Berdasarkan ketentuannya Bank Indonesia (BI) menggolongkan kualitas kredit yaitu (1) Lancar, artinya kredit yang disalurkan tidak menimbulkan masalah, (2) Dalam Perhatian Khusus, artinya kredit yang diberikan sudah mulai bermasalah, sehingga perlu memperoleh perhatian, (3) Kurang Lancar, apabila kredit yang diberikan pembayarannya sudah mulai tersendat-sendat, namun nasabah masih mampu membayar, (4) Diragukan, yaitu kemampuan nasabah untuk membayar makin tidak dapat dipastikan, dan (5) Macet, apabila nasabah sudah tidak mampu lagi untuk membayar pinjamannya, sehingga perlu diselamatkan.

\footnotetext{
${ }^{3}$ Hermansyah, 2014, Hukum Perbankan Nasional Indonesia, Kencana Prenada, Jakarta, Hal. 60
} 
Di dalam pasal 8 Undang-undang Nomor 10 Tahun 1998 tentang Perbankan menyatakan bahwa ${ }^{4}$ :

"Dalam memberikan kredit atau pembiayaan berdasarkan prinsip syariah, Bank Umum wajib mempunyai keyakinan berdasarkan analisis yang mendalam atas itikad dan kemampuan nasabah debitur untuk melunasiutangnya atau mengembalikan pembiayaan dimaksud dengan yang diperjanjikan" 5

Dengan demikian, sebelum memberikan kredit kreditur harus melakukan analisis secara ekonomi terhadap calon debitur yang dimaksudkan untuk menjaga kemungkinan terjadinya tunggakan atau kredit yang bermasalah karena hal ini akan berpengaruh terhadap kesehatan bank itu sendiri. Analisis secara ekonomi yang digunakan oleh bank terhadap calon debitur yaitu dengan menggunakan prinsip yang telah dikenal dalam dunia perbankan sebagai "Prinsip 5C" dan "Prinsip 4 P".

Prinsip 5C terdiri dari :

1. Character menyangkut kemauan debitur untuk membayar kembali kreditnya sesuai dengan yang diperjanjikan.

2. Capacitydan capital berupa kemampuan debitur untuk membayar kembali kreditnya.

3. Collateral adalah agunan atau jaminan untuk persetujuan pemberian kredit yang merupakan sarana pengaman (back up) atas resiko yang mungkin terjadi atas wanprestasinya nasabah debitur di kemudian hari.

4. Condition of Economyadalah keadaan ekonomi pada umumnya, baik ekonomi nasional maupun ekonomi internasional dan keadaan ekonomi calon debitur. ${ }^{6}$

Sedangkan Prinsip 4 P, terdiri dari :

1. Personality, menyangkut kepribadian dari calon nasabah, seperti riwayat hidup, hobi, keadaan keluarga, dan status sosial

2. Purpose menyangkut maksud dan tujuan penggunaan kredit

3. Payment adalah kemampuan calon nasabah untuk mengembalikan kreditnya

4. Prospect merupakan harapan masa depan dari usaha calon nasabah. ${ }^{7}$

Dalam dunia perbankan, kredit macet adalah kredit-kredit yang angsurannnya tidak dibayarkan sesuai dengan apa yang telah diperjanjikan sebelumnya tentang batas waktu pembayaran angsuran kredit. Dalam dunia perbankan kredit macet dapat terjadi karena

\footnotetext{
${ }^{4}$ Undang-undang Nomor 10 Tahun 1998 tentang Perbankan ${ }^{5}$ Pasal 8 Undang-undang Nomor 10 Tahun 1998 Tentang Perbankan ${ }^{6}$ Zulkifli Zaini, 2013, Memahami Bisnis Bank, PT. Gramedia Pustaka Utama, Jakarta, hal. 114

${ }^{7}$ Malayu, S.P. Hasibuan, Op.cit, hal. 108
} 
beberapa faktor, yaitu faktor intern yang berasal dari debitur seperti menurunnya kondisi bisnis, kegagalan dalam usaha, kesulitan keuangan yang serius, masalah keluarga ataupun karena watak buruk dari debitur itu sendiri.Sedangkan faktor ekstern penyebab kredit macet misalnya, dampak makro ekonomi, adanya kejadian di luar kekuasaan debitur seperti perang dan bencana alam.Selain itu, kredit macet juga dapat terjadi karena kesalahan dari pihak bank yang kurang hati- hati dalam mengenal nasabahnya.

Dalam hal wanprestasi terjadi dalam pemberian kredit oleh bank, maka dapat dipahami bahwa apabila debitur peminjam wanprestasi dalam pengertian tidak membayar angsuran bulanan sebagaimana yang diperjanjikan maka bank berhak untuk menuntut pelunasan uang pokok dan bunga atas pinjaman yang diberikan. Hal itu bisa dilakukan dengan cara menagih debitur secara langsung atau menjual agunan.

Dengan terjadinya tunggakan angsuran kredit pada Bank Rakyat Indonesia (BRI) Cabang Majene, maka pihak Bank Rakyat Indonesia (BRI) melakukan penagihan kepada Debitur secara rutin, baik dengan datang langsung ketempat domisili maupun dengan memberikan surat Penagihan/Surat Penyelesaian Tunggakan sebanyak 3 (tiga) kali. Namun, meski telah diberikan kesempatan dan waktu yang lebih dari cukup serta informasi yang patut, Debitur tetap mengabaikan peringatan-peringatan tersebut dan tetap tidak menyelesaikan kewajiban utangnya yang sudah menunggak (tetap wanprestasi).

Berdasarkan latar belakang masalah diatas, penulis tertarik untuk meneliti lebih lanjut mengenai kredit macet ini dan berpatokan pada Putusan Nomor : 35/Pdt.G.S/2018/PN.Mjn supaya dapat diperoleh gambaran yuridis upaya- upaya yang dilakukan untuk menyelesaikan kredit macet tersebut melalui kebijakan-kebijakan yang diambil pihak bank, khususnya Bank Rakya Indonesia (BRI) Cabang Majenedan mengangkat judulAnalisis Hukum terhadap Kasus Kredit Macet Pada Bank Rakyat Indonesia Cabang Majene.

\section{A. Rumusan Masalah.}

Berdasarkan latar belakang permasalahan seperti yang telah dijelaskan di atas maka dapat diambil suatu rumusan masalah, yaitu :

1. Apa yang menjadi dasar Pengadilan Negeri Majene mengadili gugatan Kredit Macet dibawah 40 juta? 
2. Bagaimana pertimbangan Hakim dalam memutuskan Perkara Nomor 35/Pdt.G.S/2018/PN.Mjn tentang Kredit Macet pada Bank Rakyat Indonesia Cabang Majene?

\section{B. Hasil Penelitian Dan Pembahasan}

a. Gambaran Umum Kedudukan Perkara Nomor : 35/Pdt.G.S/2018/PN. Mjn sebagai Objek Penelitian.

1. Pihak-pihaknya

1) INDRA BAYU WIRA PERMANA Pemimpin Cabang PT. Bank Rakyat Indonesia (BRI) (Persero) Tbk Kantor Cabang Majene, Alamat : di Jalan Jendral Gatot Subroto Nomor 17 Majene, dalam hal ini memberikan kuasa kepada ANDI IRDAN (Kepala Unit PT. Bank Rakyat Indonesia (Persero) Tbk. Unit Pasar Sentral) dan MUSTOFA KHEMAL SYAH (Mantri PT. Bank Rakyat Indonesia (Persero) Tbk. Unit Pasar Sentral), berdasarkan surat kuasa khusus Nomor : B. 1425-XIII/KC/ADK/07/2018 tanggal 5 Juli 2018, dan untuk selanjutnya disebut sebagai PENGGUGAT

\section{MELAWAN}

1) ST. AMINAH, Pekerjaan Wiraswasta, untuk selanjutnya disebut sebagai TERGUGAT I

2) SUDDIN, Pekerjaan Wiraswasta, untuk selanjutnya disebut sebagai $\underline{\text { TERGUGAT II }}$

2. Tentang Duduk Perkara

Bahwa Pihak Penggugat menggugat para Tergugat dimana para Tergugat berhutang kepada PT. Bank Rakyat Indonesia (Persero), Tbk unit Pasar Sentral Cabang Majene (Kredit Kupedes) sebesar Rp. 40.000.000,- (Empat puluh juta rupiah) selanjutnya disebut sebagai Pihak Penggugat.

1. Bahwa Para Tergugat tidak memenuhi kewajibannya / wanprestasi / ingkar janji, karena tidak melaksanakan ketentuan Pasal 2 Ayat (2) Surat Pengakuan Hutang Nomor : B.176/7469/5//2015 Tanggal 13 Mei 2015.

2. Bahwa Para Tergugat tidak membayar angsuran pinjaman sesuai dengan yang diperjanjikan dalam Surat Pengakuan Hutang sejak bulan Desember 2015 dan hingga posisi 30 Juni 2015 sisa pinjaman Tergugat menunggak dengan total sebesar Rp. 37.482.580,- (tiga puluh tujuh juta empat ratus delapan puluh dua ribu lima ratus delapan puluh rupiah) dan menjadi kredit dalam kategori kredit Macet. 
3. Bahwa akibat pinjaman Tergugat menjadi kredit Macet, Penggugat, harus menanggung kerugian, karena Penggugat harus tetap membayar bunga simpanan masyarakat yang merupakan sumber dana pinjaman yang disalurkan kepada Tergugat. Selain itu Penggugat harus membuku biaya pencadangan aktiva produktif dan Penggugat dirugikan karena tidak bisa menyalurkan pinjaman lagi ke masyarakat sebesar pinjaman Tergugat yang macet tersebut.

4. Bahwa atas kredit macet, Tergugat tersebut, penggugat telah melakukan penagihan kepada Tergugat I secara rutin, baik dengan datang langsung ke tempat domisili sebagaimana tertuang dalam Formulir Kunjungan Kepada Penunggak maupun dengan memberikan surat penagihan / Surat Penyelesaian / Tunggakan sebanyak 3 (tiga) kali. Namun, meski telah diberikan kesempatan dan waktu yang lebih dari cukup serta informasi yang patut, Tergugat I tetap mengabaikan peringatan-peringatan tersebut dan tetap tidak menyelesaikan kewajiban utangnya yang sudah menunggak (tetap wanprestasi)

5. Bahwa sesuai Surat Pengakuan Hutang seharusnya Tergugat membayar angsuran tiap-tiap bulan sebesar Rp. 2.146.700,- (Dua juta seratus empat puluh enam ribu tujuh ratus rupiah) selama 24 bulan

6. Namun Tergugat mulai tidak membayar sesuai dengan yang diperjanjikan dalam Surat Pengakuan Hutang sejak bulan Desember 2015, sehingga sampai dengan saat ini pinjaman Tergugat menunggak dengan total sebesar Rp. 37.482.580,- (tiga puluh tujuh juta empat ratus delapan puluh dua ribu lima ratus delapan puluh rupiah)

7. Bahwa dengan menunggaknya Tergugat tersebut mengakibatkan Penggugat harus membuku biaya cadangan aktiva produktif, sehingga Penggugat dirugikan dari membuku biaya ini sebesar Rp. 37.482.580,- (tiga puluh tujuh juta empat ratus delapan puluh dua ribu lima ratus delapan puluh rupiah)

8. Bahwa pada prinsipnya Penggugat hendak melakukan upaya penyelesaian tunggakan kredit Tergugat yaitu dengan cara mengambilalih/melakukan penguasaan/melakukan penjualan agunan berdasarkan Surat Pernyataan Penyerahan Agunan tanggal 13 Mei 2015 dan Surat Kuasa Menjual Agunan tanggal 13 Mei 2015, yang mana keduanya ditandatangani oleh Suddin (Tergugat II). Namun sebelum melakukan upaya-upaya tersebut, dalam rangka menyelesaikan tunggakan/kewajiban utang atas fasilitas kredit yang dinikmati Tergugat, Penggugat masih tetap memberikan waktu yang lebih dari cukup untuk 
pembayaran segala kewajiban Para Tergugat kepada Penggugat. Namun sampai gugatan ini dibuat Tergugat tetap tidak melaksanakan kewajibannya. Hal ini membuktikan bahwa Tergugat sama sekali tidak memiliki itikad baik serta telah melakukan Ingkar Janji dalam memenuhi kewajiban utangnya kepada Penggugat.

3. Amar / Putusan

Dalam Eksepsi

\section{Dalam Pokok Perkara}

- Mengabulkan gugatan Para Penggugat untuk seluruhnya

- Menghukum Para Tergugat untuk membayar biaya perkara sebesar Rp. 381.000,(tiga ratus delapan puluh satu ribu rupiah)

\section{b. Dasar Pengadilan Negeri Majene Mengadili Gugatan Kredit Macet dibawah 40} Juta

Berdasarkan ketentuan Pasal 13 Ayat (3), Pasal 18 dan Pasal 20 Peraturan Mahkamah Agung Nomor 2 Tahun 2015 Tentang Tata Cara Penyelesaian Gugatan Sederhana serta ketentuan-ketentuan hukum lainnya.

Pasal 13 Ayat (3) berbunyi : "Dalam hal tergugat tidak hadir pada hari sidang kedua, maka hakim memutus perkara tersebut"

Pasal 18 yang berbunyi :

(1) Gugatan yang diakui dan/atau tidak dibantah, tidak perlu dilakukan pembuktian.

(2) Terhadap gugatan yang dibantah, Hakim melakukan pemeriksaan pembuktian berdasarkan Hukum Acara yang berlaku.

- Pasal 20 yang berbunyi :

Sehingga yang menjadi dasar Hakim memutus suatu perkara Kredit Macet di bawah Rp. 40 juta tersebut karena pihak Nasabah dalam hal ini adalah Tergugat telah melakukan wanprestasi terhadap pihak Bank yang melanggar perjanjian yang sudah disepakati oleh pihak nasabah dan bank, Hakim dalam memutus suatu perkara tentu melihat dari bukti yang konkrit sehingga menjadi dasar untuk memutus suatu perkara. Pihak penggugat telah membuktikan bahwa tergugat telah sah melakukan wanprestasi yang terbukti di fakta persidangan sehingga Hakim telah menerima permohonan yang diajukan oleh penggugat bahwa tergugat harus mengganti kerugian Pihak Bank.

Dalam menegakkan suatu hukum ada tiga unsur yang harus selalu di perhatikan yaitu : kepastian hukum, kemanfaatan dan keadilan. Demikian juga Hakim 
dalam memutuskan suatu perkara yang diajukan di Pengadilan, bahwa putusan yang baik adalah yang memperhatikan 3 (tiga) nilai unsur yaitu yuris (kepastian hukum), nilai sosiologis (kemanfaatan), folosofis (keadaan). Kepastian hukum menekankan agar hukum atau peraturan itu ditegakan sebagaimana yang diinginkan oleh bunyi hukum/peraturannya. Adapun nilai sosiologis menekankan kepada kemanfaatan bagi masyarakat. Masyarakat mengharapkan bahwa pelaksaan hukum harus memberi manfaat, karena memang hukum adalah untuk manusia. Maka dalam melaksanakan hukum jangan sampai justru menimbulkan keresahan dalam masyarakat. Demikian juga hukum dilaksanakan bertujuan untuk mencapai keadilan. Sehingga dengan ditegakkannya hukum akan memberikan rasa keadilan bagi masyarakat. Meskipun sebenarnya keadilan itu sendiri bersifat subyektif dan individualistis. Dalam memutus suatu perkara, ketiga unsur diatas secara proposional dan seimbang. Meskipun dalam prakteknya tidak selalu mudah untuk mengusahakan kompromi terhadap unsur-unsur tersebut. $^{8}$

c. Pertimbangan Hakim dalam Memutuskan Perkara Nomor : 35/Pdt.G.S/PN. Mjn tentang Kredit Macet Pada Bank Rakyat Indonesia Cabang Majene.

\section{Pertimbangan Hakim Pengadilan Negeri Majene}

Dalam Eksepsi

Menimbang, bahwa Hakim telah mengupayakan perdamaian kepada kedua belah pihak dipersidangan, namun tidak berhasil serta Para Tergugat pada sidang pertama menyatakan mengakui dan tidak membantah /keberatan terhadap isi gugatan Penggugat terhadap utang Para Tergugat tersebut, dan dengan memperhatikan ketentuan batas waktu sebagaimana dalam Pasal 5 Ayat (3) Perma Nomor 2 Tahun 2015 tentang Tata Cara Penyelesaian Gugatan Sederhana, maka sidang dilanjutkan dengan acara pembacaan gugatan Penggugat tersebut yang isinya dipertahankan oleh kuasa Penggugat.

Menimbang, bahwa terhadap gugatan Penggugat tersebut, Tergugat di Persidangan pertama mengakui dan tidak membantah terhadap isi gugatan Penggugat tentang utang Tergugat tersebut, sehingga dengan demikian tidak dilakukan pembuktian sesuai pada Pasal 18 Ayat (1) Perma No. 2 Tahun 2015 tentang Tata Cara Penyelesaian Gugatan Sederhana.

${ }^{8}$ http://s2hukum.blogspot.com/2010/03/keyakinan-hakim-dalam-memutus-perkara.html?m=1 diakses pada tanggal 29 Mei tahun 2019, pukul 22.39 
Menimbang, bahwa untuk mempersingkat putusan perkara ini maka segala sesuatu yang terjadi dimuka persidangan dan tercatat didalam berita acara persidangan telah pula ikut dipertimbangkan dan merupakan satu kesatuan serta merupakan bagian yang tidak terpisahkan dengan putusan ini.

Dengan demikian Pertimbangan Hakim dalam Memutuskan Perkara yang debiturnya mengalami Kredit Macet dikaitkan dengan Putusan Pengadilan Negeri Majene Nomor 35/Pdt.G.S/PN.Mjn tanggal 9 Agustus 2018 dibutuhkan terlebih dahulu paparan mengenai duduk perkara yang dipermasalahkan. Hal tersebut bertujuan untuk memperoleh pemahaman menyeluruh terkait dengan permasalahan yang akan penulis bahas dan analisis, yang selanjutnya dapat dipahami alasan hukum (legal reason) dari pertimbangan hakim tersebut.

Dalam kasus kredit macet tersebut Tergugat belum memenuhi kewajibannya kepada Penggugat dan dihubungkan dengan bukti surat yang diajukan oleh Penggugat, sehingga Tergugat dapat dikualifikasikan telah melakukan wanprestasi/ingkar janji, yaitu tidak memenuhi kewajiban yang timbul dalam perjanjian tersebut.

Berdasarkan pertimbangan-pertimbangan sebagaimana diuraikan di atas, maka Hakim menilai bahwa Penggugat telah berhasil membuktikan dalil-dalil pokok yang dijadikan sebagai dasar isi gugatannya, oleh karena itu gugatan Penggugat pada pokoknya dapat dikabulkan. Mengingat Penggugat telah berhasil membuktikan dalildalil pokok gugatannya bahwa antara Penggugat dengan Para Tergugat telah terjadi perjanjian pinjam meminjam (kredit), sebagaimana Surat Pengakuan Hutang Nomor : B.176/7469/5/2015 Tanggal 13 Mei 2015, namun ternyata Para Tergugat tidak melaksanakan kesepakatan yang telah diperjanjikan tersebut, sehingga dengan demikian tindakan Para Tergugat tersebut adalah termasuk wanprestasi/ingkar janji, maka terhadap Petitum Nomor 2 pada pokoknya patut untuk dikabulkan, namun demikian sebelum menyatakan bahwa tindakan Para Tergugat tersebut adalah termasuk wanprestasi/ingkar janji, maka terlebih dahulu perlu ditetapkan bahwa kesepakatan antara Penggugat dan Para Tergugat sebagaimana tertuang dalam Surat Pengakuan Hutang Nomor : B.176/7469/5/2015 Tanggal 13 Mei 2015 Tanggal 13 Mei 2015 tersebut adalah sah dan mengikat secara hukum.

Kemudian esensi pokok tuntutan Penggugat kepada Para Tergugat adalah agar Para Tergugat memenuhi kewajibannya untuk melakukan pembayaran kepada 
Penggugat sebesar Rp. 37.482.580,- (tiga puluh tujuh juta empat ratus delapan puluh dua ribu lima ratus delapan puluh rupiah), dan apabila Para Tergugat tidak melunasi seluruh tunggakan kredit secara sukarela kepada Penggugat, maka terhadap agunan dengan bukti kepemilikan SHM 842, Dusun Galung Tengah, Kecamatan Banggae, Kabupaten Majene atas nama Suddin yang dijaminkan kepada Penggugat, dilelang dengan perantara Kantor Pelayanan Kekayaan Negara dan Lelang (KPKNL) dan hasil penjualan lelang tersebut digunakan untuk pelunasan pembayaran pinjaman/kredit Para Tergugat kepada Penggugat, maka terhadap Nomor 3 Patut untuk dikabulkan. Oleh karena itu, Para Tergugat telah dinyatakan wanprestasi/ingkar janji, maka sudah sepatutnya Para Tergugat dihukum untuk melaksanakan kesepakatan tersebut, karena gugatan Penggugat dikabulkan seluruhnya, maka para Tergugat sebagai pihak yang kalah harus dihukum untuk membayar biaya perkara yang besarnya akan ditetapkan dalam amar putusan Pengadilan Negeri Majene ini, sehingga Petitum Nomor 6 patut untuk dikabulkan.

Berdasarkan ketentuan Pasal 13 Ayat (3), Pasal 18 dan Pasal 20 Peraturan Mahkamah Agung Nomor 2 Tahun 2015 tentang Tata Cara Penyelesaian Gugatan Sederhana serta ketentuan-ketentuan hukum lainnya.

Maka dalam amar putusan Hakim Majelis menyatakan bahwa :

1) Menyatakan demi hukum perbuatan Para Tergugat adalah wanprestasi kepada Penggugat

2) Menghukum Tergugat untuk membayar lunas seketika dan tanpa syarat seluruh tunggakan kredit Tergugat I dan Tergugat II sebagaimana telah dipersyaratkan dan diperjanjikan dalam Surat Pengakuan Hutang Nomor : B.176/7469/5/2015 Tanggal 13 Mei 2015 Tanggal 13 Mei 2015 dimana total tunggakan tercatat sebesar Rp. 37.482.580,- (tiga puluh tujuh juta empat ratus delapan puluh dua ribu lima ratus delapan puluh rupiah)Apabila Tergugat tidak melunasi seluruh tunggakan kredit secara sukarela kepada Penggugat, maka terhadap agunan dengan bukti kepemilikan SHM No. 842 Dusun Galung Tengah Desa Galung Tengah, Kecamatan Banggae, Kabupaten Majene, atas nama Suddin yang dijaminkan kepada Penggugat, dilelang dengan perantara Kantor Pelayanan Kekayaan Negara dan Lelang (KPKNL) dan hasil penjualan lelang tersebut digunakan untuk pelunasan pembayaran pinjaman/kredit Tergugat kepada Penggugat. 
3) Memerintahkan kepada Tergugat atau siapa saja yang menguasai atau menempati objek agunan kepemilikan SHMNo. 842 Dusun Galung Tengah Desa Galung Tengah, Kecamatan Banggae, Kabupaten Majene, atas nama Suddin untuk segera mengosongkan objek agunan tersebut. Apabila Tergugat tidak melaksanakan sebagaimana mestinya maka atas beban biaya Tergugat sendiri pihak Penggugat dengan bantuan yang berwajib dapat melaksanakannya.

4) Menghukum Tergugta untuk membayar biaya yang timbul dalam perkara ini yang hingga kini ditaksir sejumlah Rp. 381.000,- (tiga ratus delapan puluh satu ribu rupiah).

Demikian diputuskan pada hari KAMIS tanggal 9 AGUSTUS 2018 oleh SAIFUL. HS, S.H., M.H., sebagai Hakim pada Pengadilan Negeri Majene ,putusan tersebut diucapkan dalam sidang yang terbuka untuk umum pada hari itu juga oleh Hakim tersebut dengan dibantu oleh HJ. SALMA PALOGAI, S.Pd.I. sebagai Panitera Pengganti pada Pengadilan Negeri Majene tersebut dihadiri oleh Kuasa Penggugat dan Tanpa hadirnya Para Tergugat.

Dalam perkara ini, yang menjadi Terdakwa adalah St. Aminah dan Suddin selaku Debitur (selanjutnya disebut debitur) pada Bank BRI (selanjutnya disebut bank) di Majene. Debitur telah menikmati dana dari BRI Cabang Majene sebesar Rp. 40.000.000,- (Empat puluh juta rupiah), dengan jangka waktu 24 bulan dan pengembaliannya dilakukan secara mengangsur perbulan Rp. 2.146.700,- (Dua juta seratus empat puluh enam ribu tujuh ratus rupiah) yang dimulai pada tanggal $13 \mathrm{Mei}$ 2015.

\section{d. Analisis Putusan}

Putusan Hakim dalam perkara Nomor : 35/Pdt.G.S/2018/PN.Mjn antara Indra Bayu Wira Permana (Penggugat) melawan, Siti Aminah (Tergugat I), Suddin (Tergugat II), terkait kasus kredit macet pada Bank Rakyat Indonesia Cabang Majene tersebut yang didasari pertimbangan-pertimbangan Hakim Pengadilan Negeri Majene mengenai Kasus kedua belah pihak, maka dalam hal ini analisis penulis dalam Putusan Hakim Majelis perkara Nomor 35/Pdt.G.S/2018/PN.Mjn sudah sangat jelas bahwa pertimbangan Hakim mengenai prosedur Hukum Acara Perdata dalam Perkara Nomor 35/Pdt.G.S/2018/PN.Mjn tentang pihak Debitur (Tergugat) tidak memenuhi kewajibannya / wanprestrasi / ingkar janji kepada pihak Kreditur (Penggugat), karena 
tidak membayar angsuran pinjaman sesuai dengan yang diperjanjikan dalam Surat Pengakuan Hutang sejak bulan Desember 2015 hingga 30 Juni 2018 dimana sisa pinjaman Tergugat menunggak dengan total sebesar Rp. 37.482.580,- (tiga puluh tujuh juta empat ratus delapan puluh dua ribu lima ratus delapan puluh rupiah), dan menjadi kredit macet. Berdasarkan Pasal 8 Undang-undang Nomor 10 Tahun 1998 Tentang Perbankan yang menyatakan bahwa : "Dalam memberikan kredit atau pembiayaan berdasarkan prinsip syariah, Bank Umum wajib mempunyai keyakinan berdasarkan analisis yang mendalam atas itikad dan kemampuan nasabah debitur untuk melunasi utangnya atau mengembalikan pembiayaan dimaksud dengan yang diperjanjikan". Pihak Penggugat telah melakukan penagihan kepada Tergugat I secara rutin, baik dengan datang langsung ke tempat domisili sebagaimana tertuang dalam Formulir Kunjungan Kepada Penunggak maupun dengan memberikan surat penagihan / Surat Penyelesaian Tunggakan sebanyak 3 (tiga) kali. Namun, meski telah diberikan kesempatan dan waktu yang lebih dari cukup serta informasi yang patut. Akan tetapi, Tergugat I tetap mengabaikan peringatan-peringatan tersebut dan tetap tidak menyelesaikan kewajiban utangnya yang sudah menunggak.

Pengadilan memberi keputusannya mengingat kelalaian yang dilakukan oleh pihak Nasabah (Tergugat) yakni wanprestasi/ingkar janji kepada pihak Bank Rakyat Indonesia Cabang Majene (Penggugat), sehingga langkah Hakim menjatuhkan putusan bahwa pihak Nasabah harus melunasi seluruh tunggakan kredit secara sukarela kepada Pihak Penggugat. Berdasarkan Pasal 16 UU No. 4 tahun 2004 tentang Kekuasaan Kehakiman berbunyi : "Pengadilan tidak boleh menolak untuk memeriksa, mengadili, dan memutus suatu perkara yang diajukan dengan dalih bahwa hukum tidak ada atau kurang jelas, melainkan wajib untuk memeriksa dan mengadilinya". Jika pihak Tergugat tidak melunasi seluruh tunggakan kredit tersebut kepada pihak Penggugat, maka seluruh agunan dengan bukti kepemilikan SHM 842, Dusun Galung Tengah, Kecamatan Banggae, Kabupaten Majene atas nama Suddin yang dijaminkan kepada Penggugat, dilelang dengan perantara Kantor Pelayanan Kekayaan Negara dan Lelang (KPKNL) dan hasil penjualan lelang tersebut digunakan untuk pelunasan pembayaran pinjaman/kredit Para Tergugat kepada Penggugat.

Menurut Sudikno Mertokusumo, pembuktian mengandung arti logis dan yuridis. Dalam arti Logis, adalah memberikan kepastian yang mutlak. Sedangkan dalam arti Yuridis berarti memberi dasar yang cukup kepada hakim yang memeriksa perkara 
yang bersangkutan guna memberi kepastian tentang kebenaran peristiwa yang diajukan.

Selanjutnya menurut Subekti, hukum pembuktian adalah meyakinkan hakim tentang kebenaran dalil atau dalil-dalil yang dikemukakan oleh pihak penggugat dalam suatu persengketaan. Jadi dapat disimpulkan berdasarkan beberapa pendapat diatas, bahwa jika pihak Tergugat pada saat persidangan pertama mengakui dan tidak membantah terhadap isi gugatan Penggugat tentang utang tersebut, maka tidak dilakukan pembuktian lagi sesuai dengan Pasal 18 Ayat (1) Peraturan Mahkamah Agung Nomor 2 Tahun 2015 tentang Tata Cara Penyelesaian Gugatan Sederhana. Pihak Tergugat patut dihukum karena telah melakukan ingkar janji/wanprestasi terhadap Penggugat yaitu Para Tergugat tidak memenuhi kewajibannya membayar pinjaman atau kredit sebagaimana yang tertuang dalam Surat Pengakuan Hutang Nomor : B.176/7469/5/2015

Berdasarkan beberapa pertimbangan-pertimbangan putusan tersebut diatas, yang menyatakan bahwa permohonan dari pihak Penggugat dinyatakan "Dikabulkan seluruhnya" dan menghukum Para Tergugat untuk membayar lunas seketika dan tanpa syarat seluruh tunggakan kredit Tergugat I dan Tergugat II sebagaimana telah dipersyaratkan dan diperjanjikan dalam Surat Pengakuan Hutang Nomor " B.176/7469/5/2015 Tanggal 13 Mei 2015, penulis telah menganalisis dan menyatakan bahwa pertimbangan hakim atas prosedur hukum acara perdata dalam perkara Nomor : 35/Pdt.G.S/2018/PN.Mjn sudah tepat, dimana pihak Tergugat harus membayar seluruh tunggakan kredit secara sukarela dan segera mengosongkan objek agunan dengan bukti kepemilikan SHM 842, Dusun Galung Tengah, Kecamatan Banggae, Kabupaten Majene atas nama Suddin tersebut. Apabila Pihak Tergugat tidak melaksanakan sebagaimana mestinya maka Pihak Penggugat dibantu dengan pihak yang berwajib untuk melaksanakannya.

Jadi menurut penulis dari Putusan tentang Gugatan Sederhana terhadap kasus kredit macet antara Indra Bayu Wira Permana (Penggugat) melawan, Siti Aminah (Tergugat I), Suddin (Tergugat II), terkait kasus kredit macet pada Bank Rakyat Indonesia Cabang Majene dalam Perkara Nomor : 35/Pdt.G.S/2018/PN.Mjn sudah sesuai dengan peraturan yang berlaku berdasarkan ketentuan Pasal 13 Ayat (3), Pasal 18 dan Pasal 20 Peraturan Mahkamah Agung Nomor 2 Tahun 2015 Tentang Tata 
Cara Penyelesaian Gugatan Sederhana dan ketentuan Pasal 16 UU No. 4 tahun 2004 tentang Kekuasaan Kehakiman dan Majelis Hakim sudah menerapkan peraturan secara adil.

\section{Penutup}

\section{a. kesimpulan}

Berdasarkan uraian penulis, maka penulis dapat berkesimpulan sebagai berikut :

1. Yang menjadi dasar Hakim Pengadilan Negeri Majene memutus suatu perkara Kredit Macet di bawah Rp. 40 juta tersebut Berdasarkan ketentuan Pasal 13 Ayat (3), Pasal 18 dan Pasal 20 Peraturan Mahkamah Agung Nomor 2 Tahun 2015 Tentang Tata Cara Penyelesaian Gugatan Sederhana serta ketentuan-ketentuan hukum lainnya. Karena pihak Nasabah dalam Nomor Perkara 35/Pdt.G.S/PN.Mjn adalah Tergugat telah melakukan wanprestasi terhadap pihak Bank Rakyat Indonesia Cabang Majene yang melanggar perjanjian yang sudah disepakati oleh pihak nasabah dan bank sebagaimana tertuang dalam Surat Pengakuan Hutang Nomor : B.176/7469/5/2015, Hakim Pengadilan Negeri Majene dalam memutus suatu perkara tentu melihat dari bukti yang konkrit sehingga menjadi dasar untuk memutus suatu perkara. Pihak penggugat dari Bank Rakyat Indonesia Cabang Majene telah membuktikan bahwa tergugat telah sah melakukan wanprestasi yang terbukti di fakta persidangan sehingga Hakim Pengadilan Negeri Majene telah menerima permohonan yang diajukan oleh penggugat bahwa tergugat harus mengganti kerugian Pihak Bank.

2. Pertimbangan Hakim dalam Memutuskan Perkara yang debiturnya mengalami Kredit Macet dikaitkan dengan Putusan Pengadilan Negeri Majene Nomor 35/Pdt.G.S/PN. Mjn tanggal 9 Agustus 2018 dibutuhkan terlebih dahulu paparan mengenai duduk perkara yang dipermasalahkan. Hal tersebut bertujuan untuk memperoleh pemahaman menyeluruh terkait dengan permasalahan yang akan penulis bahas dan analisis, yang selanjutnya dapat dipahami alasan hukum (legal reason) dari pertimbangan hakim tersebut.

\section{$\underline{\text { Daftar Pustaka }}$}

\section{Buku-buku}

Malayu, S.P. Hasibuan, 2007, Dasar-dasar Perbankan, PT. Bumi Aksara, Jakarta

Hermansyah, 2014, Hukum Perbankan Nasional Indonesia, Kencana Prenada, Jakarta

Zulkifli Zaini, 2013, Memahami Bisnis Bank, PT. Gramedia Pustaka Utama, Jakarta 


\section{Undang-undang}

Undang-undang Nomor 10 Tahun 1998 tentang Perbankan

Pasal 8 Undang-undang Nomor 10 Tahun 1998 Tentang Perbankan

\section{Internet}

http://s2hukum.blogspot.com/2010/03/keyakinan-hakim-dalam-memutusperkara.html?m=1diakses pada tanggal 29 Mei tahun 2019, pukul 22.39

http://www.google.com/search=Peranperbankanindonesia. Diakses tanggal 27 April 2012 